\title{
Microbial Enhanced Oil Recovery (MEOR): Alternatif Peningkatan Produksi Migas di Indonesia
}

\author{
Desy Hikmatul Siami ${ }^{1}$ dan Novi Hery Yono $^{2}$
}

\begin{abstract}
ABSTRAK
Kebutuhan minyak bumi semakin meningkat seiring perkembangan industry, sedangkan hasil produksi pengambilan minyak dari reservoir dengan menggunakan primary recovery dan secondary recovery masih sangat rendah sehingga dibutuhkan tahapan lanjutan yaitu tertiary recovery salah satunya adalah Enhanced Oil Recovery (EOR). EOR terbukti mampu meningkatkan produksi mencapai 50\%. EOR terdiri dari berbagai aplikasi, mulai dari injeksi air, injeksi gas, injeksi bahan kimia hingga injeksi mikrobiologi. Tahapan pada injeksi air dan gas masih menyisakan minyak yang terperangkap dalam bebatuan di reservoir. MEOR merupakan salah satu metode yang dapat digunakan untuk membawa minyak yang terperangkap di bebatuan reservoir ke permukaan. Efektivitas dari metode MEOR diukur berdasarkan beberapa parameter yaitu formasi suhu, viskositas minyak, permeabilitas, salinitas air garam, water cut, gravitasi API crude oil, pH, tekanan, saturasi oil residu, kedalaman porositas dan kandungan bakteri pada reservoir.
\end{abstract}

Kata kunci: EOR, MEOR, Mikrobiologi

\section{ABSTRACT}

The need for petroleum is increasing along with the development of the industry, while the production results from the process of recovering oil from the reservoir by using primary recovery and secondary recovery are still very low so that it takes an advanced stage, namely tertiary recovery or, known as EOR. EOR is a method that produces oil production above 50\%. EOR is an effort to increase oil production, so it is included in the IOR (Improved Oil Recovery) section. EOR consists of various applications, ranging from water injection, chemical injection, gases injection to microbiology injection. The stages in the injection of water and gas still leave oil trapped in the rocks in the reservoir. MEOR is one method that can be used to bring oil trapped in reservoir rocks to the surface. The effectiveness of the MEOR method is measured based on several parameters that is formation temperature, oil viscosity, permeability, saltwater salinity, water cut, API gravity crude oil, $\mathrm{pH}$, pressure, residual oil saturation, porosity depth and bacterial content in the reservoir.

Keywords: EOR, MEOR, Microbiologi

Fakultas Teknik, Universitas Negeri Semarang, Semarang

2 Pusat Pengembangan Sumber Daya Manusia Minyak dan Gas Bumi, Cepu 


\section{PENDAHULUAN}

Permintaan minyak bumi semakin meningkat sejalan dengan perkembangan industry yang makin pesat, sedangkan penemuan cadangan reservoir baru masih sangat sulit ditemukan (Rita, 2012). Salah satu upaya untuk memenuhi kebutuhan minyak bumi maka dengan mengoptimasi sumber minyak (reservoir) yang sudah ada, namun dewasa ini eksploitasi minyak bumi masih jauh dari kata optimal karena belum memanfaatkan seluruh kandungan minyak bumi dan juga metode produksi yang masih konvensional (Nugroho, 2010). Dalam tahapan proses produksi minyak kandungan yang terdapat di reservoir tidak dapat terkuras dengan habis karena berbagai fenomena, selain itu penurunan hasil produksi juga disebabkan karena sumur yang sudah tua dengan water cut lebih dari $90 \%$ sehingga perlu metode lanjutan untuk meningkatkan proses produksi (Wicaksono and Yuliansyah, 2015). ${ }^{1}$

Menurut (Rita, 2012) proses produksi minyak bumi dibagi dalam beberapa proses produksi yaitu primary recovery, secondary recovery and tertiary recovery (EOR). Proses Primary recovery diproduksi secara alamiah pada sumur sumber minyak dan gas dengan terkanan reservoir menggunakan pompa atau gas lift dengan tujuan untuk mempermudah aliran fluida. Secondary recovery menggunakan bantuan air dan gas bertekanan untuk mendorong fluida, sedangkan pada tertiary recovery atau Enhanced Oil Recovery dilakukan dengan cara injeksi $\mathrm{CO}_{2}$, zat kimia, steam, penggunaan mikroba (MEOR), dan bahan penginjeksi lainnya (ESDM, 2014). Presentase hasil yang didapatkan setiap prosesnya berbeda, karena pengaruh dari bantuan penginjeksi yang mempengaruhi laju dan pergerakan fluida menuju permukaan.

Tujuan Penelitian ini menjelaskan metode En-

1 where the polymer is dissolved in water, usually the formation water. Hydrolyzed polyacrylamide (HPAM hanced Oil Recovery (EOR) dengan berbagai proses, lebih spesifik menggunakan Mikroba melalui berbagai penelitian yang telah ada. Studi ini juga memberikan gambaran jenis mkroorganisme yang digunakan dalam metode MEOR sehingga dapat menjadi salah satu alternatif pemilihan metode.

\section{PEMBAHASAN}

\section{A. Enhanced Oil Recovery (EOR)}

Proses Produksi secara primary dan secondary yang telah dilakukan tidak optimal, karena masih terdapat saturasi minyak di dalam reservoir (remaining oil saturation, ROS), maka perlu proses lanjutan untuk mengurangi tingkat saturation oil yang tersisa di reservoir (Rita, 2012). Enhanced Oil Recovery (EOR) dapat disebut juga sebagai tertiary recovery. Enhanced Oil Recovery merupakan proses produksi selain dari primary dan secondary recovery. Metode EOR di pakai untuk meningkatkan hasil produksi minyak dari prosesproses sebelumnya mencapai lebih dari $50 \%$ (Nugroho, 2010)(Maneeintr, Chewaroungroaj and Boonpramote, 2020) ${ }^{2}$ dilihat pada Gambar. 1. yang dideskripsikan oleh Society Petroleum Engineer (SPE).

Secara spesifik EOR dapat didefinisikan sebagai proses recovery dengan menginjeksi cairan dengan atau tanpa aditif ke sumber minyak (reservoir) untuk mengubah sifat minyak serta memberi tekanan dan dorongan agar minyak dapat muncul ke permukaan (Babadagli, 2020) (J. Sheng, 2010). Skema klasifikasi metode EOR dipaparkan pada Gambar. 2 dengan minimal satu injektor dan satu reservoir.

2200 meters and the sand thickness is varied from of 1 to 7 meters. For over 60 years of natural production, the field has low oil recovery. The difficulty has been attributed to the unfavorable production. Waterflooding, a secondary recovery, has been studied and the results show that the recovery can increase $4-6 \%$. However, the production can be enhanced more with the tertiary recovery methods or enhanced oil recovery (EOR). 


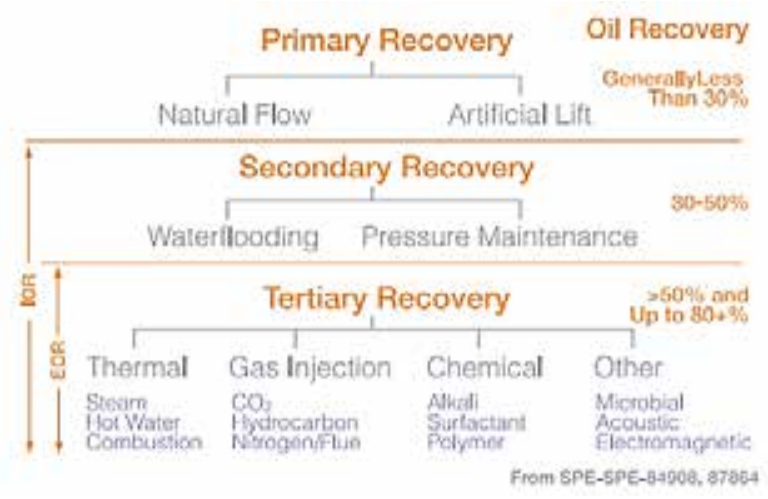

Gambar 1. Oil Recovery and Recovery Factors (Kokal and Al-Kaabi, 2010)

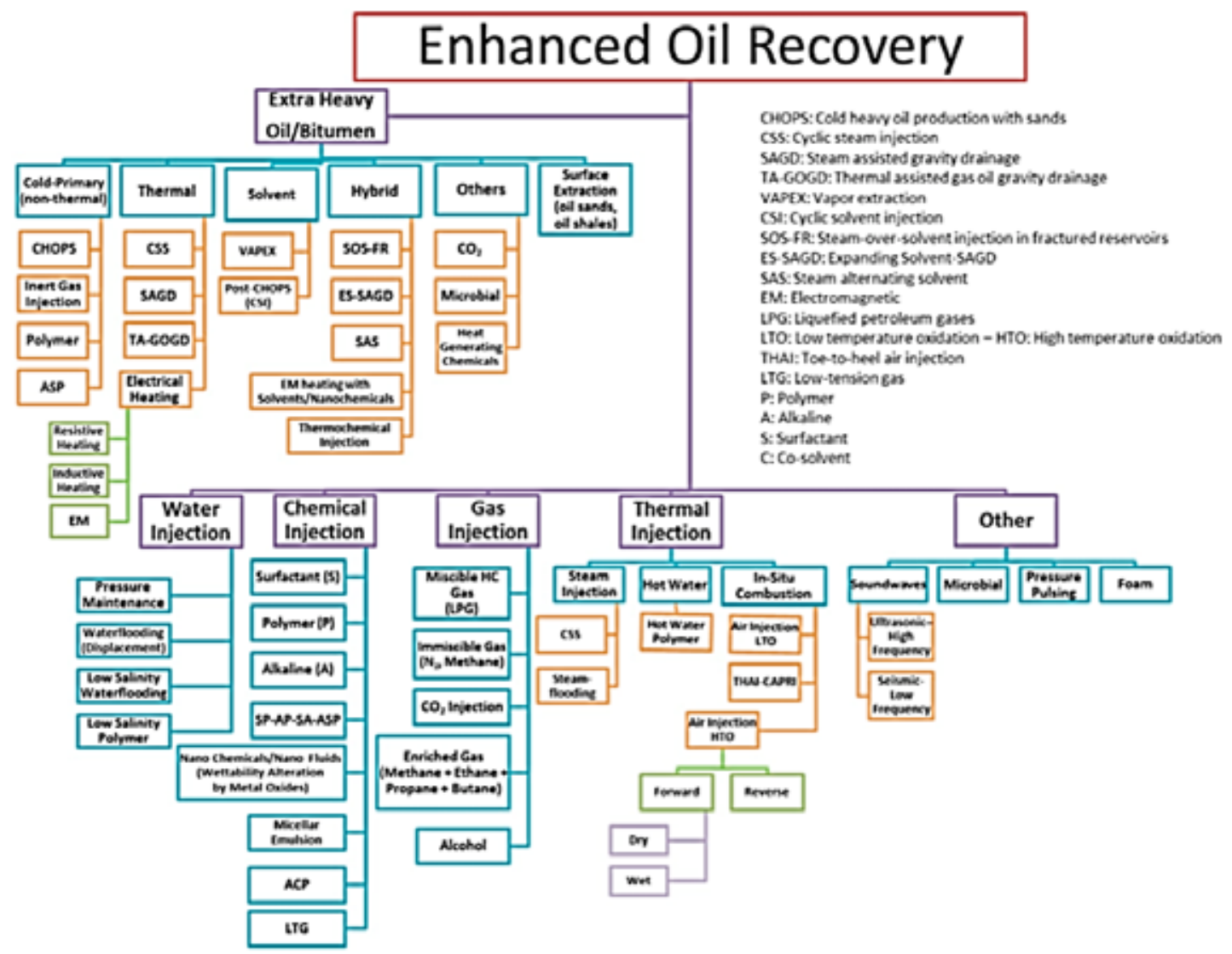

Gambar 2. Klasifikasi Metode Enhanced Oil Recovery (EOR) (Babadagli, 2020)

Aplikasi yang digunakan pada EOR adalah dengan menginjeksi bahan kimia, gas atau thermal energy ke dalam reservoir (Belhaj et al., 2020). Pemakaian bahan kimia seperti surfaktan, polymer, emulsifier, asam, solvent, di aplikasi kan untuk mempermudah aliran minyak yang terperangkap setelah waterflooding pada (secondary recovery) karena dianggap injeksi air tidak cukup untuk membawa minyak ke permukaan (Purwasena et al., 2019) ${ }^{3}$

3 isolation and screening for potential biosurfactant-producing bacteria from crude oil samples was performed, followed by their characterization. A biosurfactant core flooding experiment was also conducted to examine bacterial activity on MEOR. Thirty-one sequential isolates of bacteria were screened based on qualitative and semi-qualitative parameters. One selected biosurfactant-producing bacterium was identified as Bacillus licheniformis DS1 based on phylogenetic analysis of the $16 \mathrm{~S}$ rRNA gene. This bacteri- 
(Alvarez et al., 2020) ${ }^{1}$. Metode EOR ditujukan untuk meningkatkan nilai dari perolehan minyak maka dari itu EOR merupakan bagian dari IOR (Improved Oil Recovery) (Makky and Kasmungin, 2019). Sehingga faktor keberhasilan metode EOR adalah dengan adanya peningkatan pada hasil produksi minyak. Peningkatan produksi minyak pada EOR dapat dilihat dari gambar 3 .

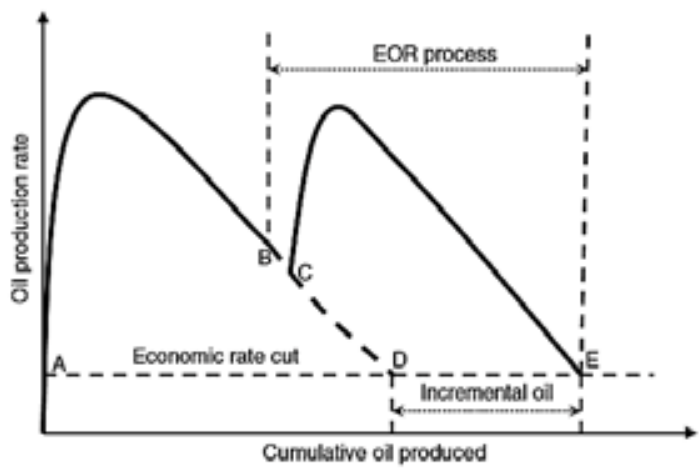

Gambar 3. Peningkatan Hasil Produksi Minyak pada Proses EOR (J. Sheng, 2010)

Grafik tersebut menunjukkan laju produksi minyak menyeluruh dari A ke B. Apabila metode EOR mulai dilakukan pada titik B, laju hasil produksi minyak yang di harapkan adalah B ke E. Namun, apabila proses EOR tidak di-

um had the highest emulsification activity (Ei24 $=65.19 \%$ 1 1044.6511, 1058.6661 and 1072.6848. They were constituted of fatty acids varying from $\mathrm{C} 13$ to $\mathrm{C} 16$; however about $70 \%$ of the isoforms showed $\mathrm{m} / \mathrm{z}$ of 1058.6661 and the fatty acid C15. Based on the AB2.0 genome sequence, only one gene group related to surfactin biosynthesis was found. Strain AB2.0 produced $99.6 \mathrm{mg} / \mathrm{l}$ of surfactin in $\mathrm{Tr}$ yptic Soy Broth after $48 \mathrm{~h}$. The biosurfactant presented an emulsification activity of $45.7 \%$ in this growth condition. It considerably decreased the water surface tension from $72.0 \mathrm{mN} / \mathrm{m}$ to $24.7 \mathrm{mN} / \mathrm{m}$ and the interfacial tension of n-hexadecane from $30.1 \mathrm{mN} / \mathrm{m}$ to $7.5 \mathrm{mN} / \mathrm{m}$, as well as of a medium crude oil from $42.3 \mathrm{mN} / \mathrm{m}$ to $6.9 \mathrm{mN} / \mathrm{m}$ and of a light crude oil from 36.4 to $3.8 \mathrm{mN} / \mathrm{m}$. Calcite flotation test was conducted to access the wettability reversal of the biosurfactant in high salinity condition similar to that observed in an oil production reservoir, and AB2.0 reversed $100 \%$ using concentrations as low as 25 ppm of biosurfactant. Oil contaminated sand columns were used to simulate microbial enhanced oil recovery at different temperatures and high salinity. When surfactin from AB2.0 was added to the sand columns, the TPH concentration in liquid phases recovered was enhanced up to $24 \times$ indicating that AB2.0 is an excellent candidate for its application in MEOR in subsurface environments. http://www.mendeley.com/documents/?uuid = bb54a9e4-78e2-4501-901f-df541606fbb3, Alvarez et al., 2020. mulai pada titik B maka diperkirakan laju minyak akan jatuh lebih jauh terlihat pada grafik C ke D.

\section{B. Microbial Enhanced Oil Recovery (MEOR)}

MEOR termasuk kedalam tertiary oil recovery atau kita kenal dengan Enhance Oil Recovery yang teknologi nya berbasis biological dengan metode metabolisme mikroba (biomassa, biopolimer, gas, asam, pelarut, enzym dan karbon aktif) dan aktivitas (metabolisme hidrokarbon, plugging) yang digunakan untuk meminimalisir residu minyak yang tertinggal pada reservoir (Purwasena et al., 2019) ${ }^{2}$. Microbial Enhanced Oil Recovery (MEOR) menjadi teknologi yang sudah mendapatkan visibilitas atas kemampuannya meningkatkan hasil produksi minyak pada dekade terakhir yang menggunakan bakteri atau bio-produk (Rocha et al., 2020).

Kebanyakan metode EOR tidak efisien dalam hal ekonomi dan tidak aman untuk lingkungan, kecuali MEOR yang memiliki biaya lebih rendah, rendah kerusakan, bioekuivalen, dan biodegradabilitas (Purwasena et al., 2019) ${ }^{3}$ (Haloi et al., 2020). Proses MEOR dimulai dari injeksi mikroba ke reservoir hingga munculnya minyak ke permukaan dapat dilihat pada gambar 4. Mikroba yang diinjeksikan

2 Isolation and screening for potential biosurfactant-producing bacteria from crude oil samples was performed, followed by their characterization. A biosurfactant core flooding experiment was also conducted to examine bacterial activity on MEOR. Thirty-one sequential isolates of bacteria were screened based on qualitative and semi-qualitative parameters. One selected biosurfactant-producing bacterium was identified as Bacillus licheniformis DS1 based on phylogenetic analysis of the $16 \mathrm{~S}$ rRNA gene. This bacterium had the highest emulsification activity (Ei24 $=65.19 \%$

3 Isolation and screening for potential biosurfactant-producing bacteria from crude oil samples was performed, followed by their characterization. A biosurfactant core flooding experiment was also conducted to examine bacterial activity on MEOR. Thirty-one sequential isolates of bacteria were screened based on qualitative and semi-qualitative parameters. One selected biosurfactant-producing bacterium was identified as Bacillus licheniformis DS1 based on phylogenetic analysis of the $16 \mathrm{~S}$ rRNA gene. This bacterium had the highest emulsification activity $(\mathrm{Ei} 24=65.19 \%$ 
akan mengikat minyak yang terperangkap pada resevoir kemudian membawanya keluar kepermukaan.

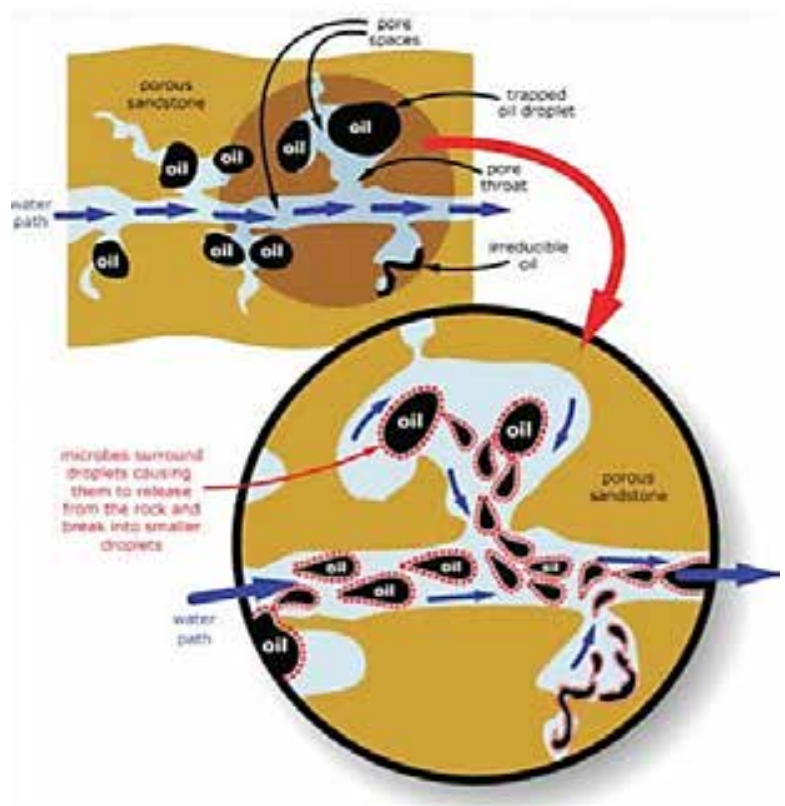

Gambar 4. Ilustrasi MEOR pada reservoir minyak (Ansyori, 2018)

Apabila EOR minimal dilakukan pada satu reservoir, metode MEOR kebanyakan diaplikasikan pada 2 reservoir seperti mekanisme in-situ dan ex-situ (Saravanan et al., 2020). MEOR pada mekanisme in-situ mikroba dan nutrien diinjeksikan ke reservoir melalui sumur injeksi sedangkan pada ex-situ mikroba di produksi pada bioreaktor terlebih dahulu kemudian di injeksikan ke reservoir, kedua metode ini memiliki perbedaan yang dapat dilihat pada Tabel 1 (Niu et al., 2020).

Tabel 1. Perbedaan In-situ and Ex-situ MEOR

\begin{tabular}{lll}
\hline No & \multicolumn{1}{c}{ In-situ MEOR } & \multicolumn{1}{c}{ Ex-situ MEOR } \\
\hline 1. & $\begin{array}{l}\text { Bakteri dan Nutrien di } \\
\text { injeksikan langsung } \\
\text { ke reservoir }\end{array}$ & $\begin{array}{l}\text { Bakteri di produksi } \\
\text { di dalam bioreaktor } \\
\text { kemudian diinjeksikan } \\
\text { ke reservoir }\end{array}$ \\
\hline
\end{tabular}

\begin{tabular}{lll}
\hline No & \multicolumn{1}{c}{ In-situ MEOR } & \multicolumn{1}{c}{ Ex-situ MEOR } \\
\hline 2. & $\begin{array}{l}\text { Biaya yang digunakan } \\
\text { lebih rendah }\end{array}$ & $\begin{array}{l}\text { Biaya yang digunakan } \\
\text { mahal }\end{array}$ \\
\hline 3. & $\begin{array}{l}\text { Efek yang ditimbulkan } \\
\text { tidak signifikan }\end{array}$ & $\begin{array}{l}\text { Efek yang ditimbulkan } \\
\text { signifikan }\end{array}$ \\
\hline 4. & $\begin{array}{l}\text { Output hasil produksi } \\
\text { rendah }\end{array}$ & $\begin{array}{l}\text { Ouput hasil produksi } \\
\text { tinggi }\end{array}$ \\
\hline 5. & $\begin{array}{l}\text { Kesulitan pada } \\
\text { screening microba }\end{array}$ & Perlu screening \\
\hline
\end{tabular}

Efektivitas dari metode MEOR diukur berdasarkan beberapa parameter: formasi suhu, viskositas minyak, permeabilitas, salinitas air garam, water cut, gravitasi API crude oil, $\mathrm{pH}$, tekanan, saturasi oil residu, kedalaman porositas dan kandungan bakteri pada reservoir (Saravanan et al., 2020). Parameter Saturasi Oil Residu (SOR) ditentukan oleh angka kapilaritas $\left(\mathrm{N}_{\text {Cap }}\right)$ yang di dapat dari perbandingan pada persamaan (1) (Niu et al., 2020).

Ncap $=\frac{\text { Viscous Force }}{\text { Capillarity Force }}=\frac{v \cdot \mu}{\sigma \cos \theta}$

dimana dan kecepatan perpindahan fluida, adalah IFT antara fluida yang dipindahkan dan fluida yang memindahkan.

\section{Microbial Product in MEOR}

Proses MEOR menginjeksikan mikroba dan juga nutrien, fungsi nutrien yang diinjeksikan ke dalam reservoir adalah sebagai sumber pangan untuk pertumbuhan mikroba dan aktivitas metabolisme (Liu, 2010). Mikroba juga dapat menghasilkan biosurfaktan, biopolimer, asam, pelarut, gas campuran dan enzym yang dapat meningkatkan efisiensi pengangkatan minyak ke permukaan, gambar zona produk dari mikroba dapat dilihat pada gambar 5 (Zhang, Gao and Xue, 2020). 


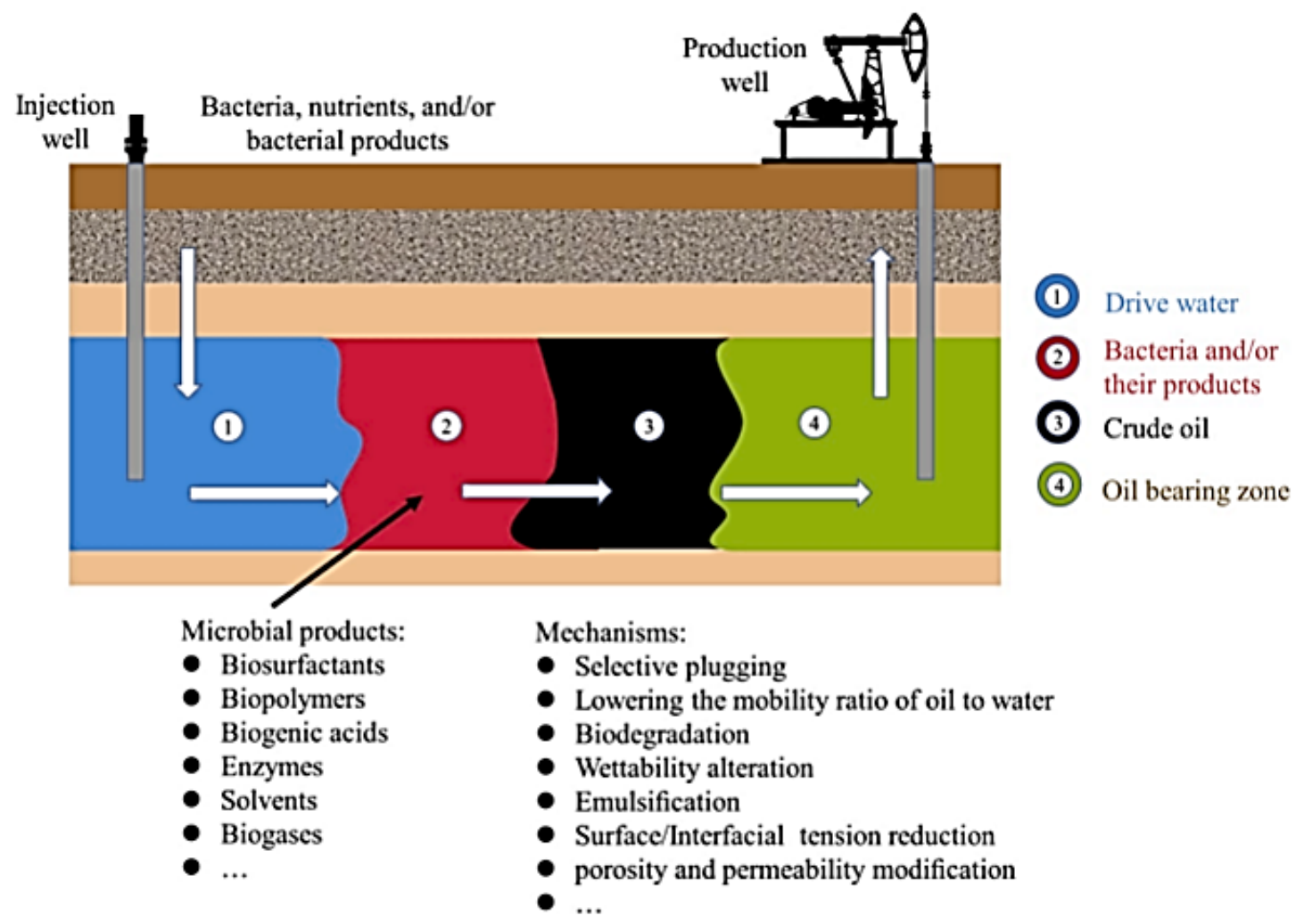

Gambar 5. Zona Produk yang dihasilkan Mikroba

Mikroorganisme yang digunakan memiliki yang telah digunakan pada MEOR dapat dilivariasi yang beragam sesuai dengan jenis pro- hat pada tabel 2 . duk yang dihasilkan. Bebagai macam mikroba

Tabel 2. Produk hasil dari Mikroorganisme yang digunakan pada MEOR (Niu et al., 2020; Zhang, Gao and Xue, 2020)

\begin{tabular}{ll}
\hline \multicolumn{1}{c}{ Produk Mikroba } & \multicolumn{1}{c}{ Jenis Mikoorganisme } \\
\hline Biosurfactan & Bacillus sp., Pseudomonas sp., Rhodococcus sp., Acinetobacter sp., Bombicola \\
\hline Biopolimer & $\begin{array}{l}\text { Xanthomonas sp., Aureobasidium sp., Bacillus sp., Leuconostoc sp., Alcaligenes } \\
\text { sp., Lactobacillus suebicus., Pediococcus parvulus., Halomonas sp., }\end{array}$ \\
\hline Produk Mikroba & Jenis Mikoorganisme \\
\hline Biomasa & Pseudomonas sp., Bacillus sp., Leuconostoc sp., Xanthomonas sp \\
\hline Biogas & Bacillus sp., Brevibacterium sp., Clostridium sp., Methanobacterium sp., \\
& Enterobacter sp. \\
\hline Enzymes & Acinetobacter sp., Bacillus sp., Dietzia sp., Pseudomonas sp., Micrococcus sp., \\
\hline Acids and solvents & Rhodococcus sp. \\
\hline
\end{tabular}




\section{KESIMPULAN}

MEOR merupakan teknologi yang lebih efektif untuk meningkatkan hasil produksi minyak dengan basis biologi yang menggunakan mikroba. MEOR dapat digunakan pada dua jenis reservoir, in-situ dan ex-situ MEOR. Efektivi- tas MEOR dinilai dari beberapa parameter, yaitu formasi suhu, viskositas minyak, permeabilitas, salinitas air garam, water cut, gravitasi API crude oil, $\mathrm{pH}$, tekanan, saturasi oil residu, kedalaman porositas dan kandungan bakteri pada reservoir. Mikroba yang digunakan pada MEOR juga menghasilkan beberapa produk.

\section{REFERENSI}

Alvarez, V. M. et al. (2020) 'Microbial enhanced oil recovery potential of surfactin-producing Bacillus subtilis AB2.0', Fuel. Elsevier, 272(April), p. 117730. doi: 10.1016/j. fuel.2020.117730.

Ansyori, M. R. (2018) 'Mengenal Enhanced Oil Recovery ( EOR ) Sebagai Solusi Meningkatkan Produksi Minyak', Swara Patra, 8(2), pp. 16-22. Available at: http://ejurnal. ppsdmmigas.esdm.go.id/sp/index.php/swarapatra/article/view/25.

Babadagli, T. (2020) 'Journal of Petroleum Science and Engineering Philosophy of EOR', 188(November 2019). doi: 10.1016/j.petrol.2020.106930.

Belhaj, A. F. et al. (2020) 'The effect of surfactant concentration, salinity, temperature, and pH on surfactant adsorption for chemical enhanced oil recovery: a review', Journal of Petroleum Exploration and Production Technology. Springer International Publishing, 10(1), pp. 125-137. doi: 10.1007/s13202-019-0685-y.

ESDM (2014) Lebih Jauh Tentang Eksplorasi dan Produksi Migas / Situs Ditjen Migas. Available at: https://migas.esdm.go.id/post/read/Lebih-Jauh-Tentang-Eksplorasi-dan-ProduksiMigas (Accessed: 17 June 2020).

Haloi, S. et al. (2020) 'Characterization of Pseudomonas sp. TMB2 produced rhamnolipids for ex-situ microbial enhanced oil recovery', 3 Biotech. Springer International Publishing, 10(3), pp. 1-17. doi: 10.1007/s13205-020-2094-9.

J. Sheng, J. (2010) Modern Chemical Enhanced Oil Recovery; Theory and Practice.

Kokal, S. and Al-Kaabi, A. (2010) 'Enhanced oil recovery: challenges and opportunities', Global Energy Solutions, pp. 64-69. Available at: http://www.world-petroleum.org/docs/ docs/publications/2010yearbook/P64-69_Kokal-Al_Kaabi.pdf.

Liu, S. (2010) Bioprocess engineering; Kinetics, Sustainability, and Reactor Design, Process Biochemistry. doi: 10.1016/j.procbio.2010.09.002.

Makky, H. and Kasmungin, S. (2019) 'Peningkatan Perolehan Minyak Dengan Optimalisasi Proyek Cyclic Steam Stimulation Menggunakan Metode Simulasi Reservoir Di Lapangan-X, Sentral Sumatera', Journal of Chemical Information and Modeling, 53(9), pp. 1689-1699. doi: 10.1017/CB09781107415324.004.

Maneeintr, K., Chewaroungroaj, J. and Boonpramote, T. (2020) 'Enhanced oil recovery: Potential for oil production development in Fang oilfield, Thailand', IOP Conference Series: Earth and Environmental Science, 463(1). doi: 10.1088/1755-1315/463/1/012063. 
Niu, J. et al. (2020) 'Review on microbial enhanced oil recovery: Mechanisms, modeling and field trials', Journal of Petroleum Science and Engineering. Elsevier B.V., 192(January), p. 107350. doi: 10.1016/j.petrol.2020.107350.

Nugroho, A. (2010) 'Produksi Gas Hasil Biodegradasi Minyak Bumi: Kajian Awal Aplikasinya Dalam Microbial Enhanced Oil Recovery (Meor)', MAKARA of Science Series, 13(2), pp. 111-116. doi: 10.7454/mss.v13i2.405.

Purwasena, I. A. et al. (2019) 'Stability test of biosurfactant produced by Bacillus licheniformis DS1 using experimental design and its application for MEOR', Journal of Petroleum Science and Engineering, 183(February). doi: 10.1016/j.petrol.2019.106383.

Rita, N. (2012) 'Studi Mekanisme Injeksi Surfaktan-Polimer pada Reservoir Berlapis Lapangan NR Menggunakan Simulasi Reservoir', Journal of Earth Energy Engineering, 1(1), pp. 22-36. doi: 10.22549/jeee.v1i1.926.

Rocha, V. A. L. et al. (2020) 'Comparison of mono-rhamnolipids and di-rhamnolipids on microbial enhanced oil recovery (MEOR) applications', Biotechnology Progress. doi: 10.1002/btpr.2981.

Saravanan, A. et al. (2020) 'A review on systematic approach for microbial enhanced oil recovery technologies: Opportunities and challenges', Journal of Cleaner Production. Elsevier B.V., 258. doi: 10.1016/j.jclepro.2020.120777.

Wicaksono, H. and Yuliansyah, A. T. (2015) 'Karakterisasi Larutan Polimer KYPAM HPAM untuk Bahan Injeksi dalam Enhanced Oil Recovery (EOR)', Karakterisasi Larutan Polimer KYPAM HPAM untuk Bahan Injeksi dalam Enhanced Oil Recovery (EOR), 9(1), pp. 9-15. doi: 10.22146/jrekpros.24524.

Zhang, J., Gao, H. and Xue, Q. (2020) 'Potential applications of microbial enhanced oil recovery to heavy oil', Critical Reviews in Biotechnology. Taylor \& Francis, 40(4), pp. 459-474. doi: 10.1080/07388551.2020.1739618. 